\title{
Effektivitas Komite Audit, Dewan Komisaris Independen dan Biaya Audit
}

\author{
Fitri Nurjanah ${ }^{1}$ \\ Fakultas Ekonomi \\ Akhmad Imam Amrozi ${ }^{2}$ \\ Fakultas Ekonomi \\ Universitas Islam Lamongan, Indonesia Universitas Islam Lamongan, Indonesia
}

Surel : fitrinurjanah129@gmail.com

\section{ABSTRAK}

Tujuan dari penelitian ini adalah untuk menganalisis pengaruh efektivitas komite audit dan dewan komisaris independensi terhadap biaya audit. Penelitian ini menggunakan sampel perusahaan non-finansial di Bursa Efek Indonesia (BEI) pada 2015-2018. Teknik pengambilan sampel menggunakan purposive sampling. Jumlah total perusahaan yang digunakan sebagai sampel penelitian adalah 584 perusahaan. Menggunakan alat SPSS 20 dan menguji hipotesis menggunakan regresi linier. Uji F menunjukkan model yang stabil dan signifikan. R square adalah $49,4 \%$. Hasilnya menunjukkan independensi dewan komisaris dan efektivitas komite audit berpengaruh positif signifikan terhadap biaya audit karena komite audit yang efektif dan dewan komisaris independen menginginkan kualitas audit yang lebih tinggi dari auditor.

Kata Kunci: Dewan Komisairis; Efektivitas Komite Audit; Auidt Fee.

\section{Effectiveness of the Audit Committee, Independent Board of Commissioners and Audit Costs}

\section{ABSTRACT}

The purpose of this study is to analyze the effect of effectiveness of audit committee and independence board of commissioner on audit fee. This research uses samples of Non-financial companies in Indonesia Stock Exchange (IDX) in 2015-2018. The sampling technique used purposive sampling. The total number of companies used as research samples is 584 companies. Using tools SPSS 20 and testing hypothesis using linear regression. The $F$ test indicates a stable and significant model. $R$ square is $49,4 \%$ The result show independence board of commissioner and Effectiveness of audit committee can positively significant effect on audit fee because board of commissioners and audit committee wants a higher audit quality from the auditor.

Keywords: Board Of Commissioners; Effectiveness Of Audit Committee; Audit Fee.

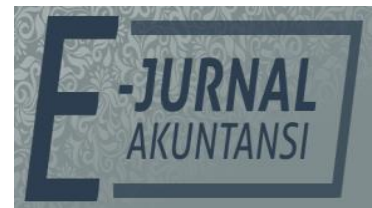

e-ISSN 2302-8556

Vol. 31 No. 3

Denpasar, Maret 2021

Hal. 667-676

DOI:

10.24843/EJA.2021.v31.i03.p11

PENGUTIPAN:

Nurjanah, F., \& Amrozi, A.I.

(2021). Effektivitas Komite Audit, Dewan Komisaris

Independen dan Biaya Audit. E-Jurnal Akuntansi, 31(3), 667-676

RIWAYAT ARTIKEL: Artikel Masuk: 1 September 2019 Artikel Diterima: 24 Maret 2021

Artikel dapat diakses : https://ojs.unud.ac.id/index.php/Akuntansi/index 


\section{PENDAHULUAN}

Profesi akuntan publik menjadi salah satu profesi yang dipercaya untuk memberikan rasa yakin bagi para shareholder dan stakeholder terkait audit laporan keunagan dan pemberian opini atas laporan keuangan yang diterbitkan oleh perusahaan yang merupakan kondisi dan gamparan yang terkait kinerja perusahaan. Akuntan publik memiliki tugas yang untuk meningkatkan keandalan dari laporan keuangan perusahaan agar bisa digunakan sebagai alat pengambil keputusan ekonomi (Arnold et al., 2012).

Laporan keuangan yang telah diaudit oleh auditor eksternal dapat mengurangi konflik antara principal dan agen (Jensen \& Meckling, 1976). Untuk mengurangi konflik kepentingan prinsipal melakukan pemantauan untuk memantau kinerja agen dengan pemeriksaan oleh auditor eksternal. Prosedur pemantauan dapat meningkatkan biaya agensi (Jensen \& Meckling, 1976). Biaya agensi merupakan biaya yang dikeluarkan oleh principal untuk melakukan prosedur audit terhadap perusahaan (Francis \& Wilson, 1988).

Biaya audit memiliki banyak faktor yang mempengaruhi seperti resiko yang dimiliki perusahaan, besaran industry, komite audit dan dewan komisaris independen. Komite audit dan komisaris independen merupakan bagian dari tata kelola perusahaan. Tata kelola perusahaan dapat dikatakan baik apabila memenuhi standart yang diterapkan pada Organisation for Economic Co-operation and Development (OECD). Tata kelola perusahaan berkaitan dengan fungsi pengawasan yang dilakukan oleh dewan komisaris dengan membentuk komite di bawah mereka, salah satunya adalah Komite Audit.

Beberapa hasil penelitian efektivitas komite audit terhadap biaya audit. Penelitian yang dilakukan (Ghanem et al, 2016) dan (Collier \& Gregory, 2006) bahwa efektivitas komite audit berpengaruh positif biaya audit dikarenakan dengan keberadaan komite audit yang efektif pada suatu perusahaan dianggap dapat menyediakan sistem pengawasan yang lebih objektif. Sistem pemantauan yang efektif akan menghasilkan permintaan untuk kualitas audit yang lebih baik. Ini nantinya akan memiliki implikasi untuk biaya audit yang lebih besar (Hay et al, 2006).

Kebijakan penentuan biaya audit sudah diatur dalam peraturan IAPI nomor 2 tahun 2016 hanya menyebutkan bahwa besarnya fee anggota dapat bervariasi tergantung pada resiko penugasan, kompleksitas jasa yang diberikan, tingkat keahlian yang diperlukan, struktur biaya KAP yang bersangkutan, dan pertimbangan professional lainnya. IAPI melaporkan pada tahun 2016 bahwa penerapan mekanisme regulasi tidak optimal sampai saat ini. Akuntan publik bersertifikat masih banyak yang tidak mengungkapkan bagaimana cara mereka menentukan jumlah biaya audit yang akan diterima.

Gap penelitian dari penelitian sebelumnya adalah penggunaan efektivitas Dewan Komisaris dan Komite Audit daripada indeks tata kelola perusahaan yang baik secara keseluruhan seperti dalam Wahab et al (2011). Studi ini akan fokus pada efektivitas Dewan Komisaris dan Komite Audit dalam melakukan sistem pengawasan mereka sebagai salah satu elemen tata kelola perusahaan yang diyakini sebagai faktor yang paling berpengaruh untuk menentukan biaya audit. Menimbang bahwa Dewan Komisaris dan Komite Audit memiliki 
wewenang untuk berkomunikasi dengan auditor dan untuk menentukan ruang lingkup pekerjaan audit.

Penelitian ini menggunakan tiga varibael kontrol untuk menguatkan model. Variabel yang digunakan yakni return on asset (ROA), ukuran perusahaan yang diukur menggunakan logaritma natural dari asset, dan kantor akuntan publik. Ketiga variabel ini banyak digunakan sebagai kontrol pada model penelitian biaya audit (Ariningrum, 2017), (Simunic, 1990), dan (Gul, 2006).

Perusahaan menggunakan sistem good corporate governance, di Indonesia menerapkan system two tier dalam tata kelola perusahaan. Organ tertinggi perusahaan yang memiliki fungsi pengawasan yakni dewan komisaris, untuk membantu menjalankan fungsi pengawasan dewan komisaris membentuk komite audit, komite audit dalam membantu melakukan pengawasan. Sehubungan dengan biaya audit, ada dua argumen yang menggambarkan pengaruh efektivitas Komite Audit terhadap biaya audit.

Argument pertama dalam sisi penawaran yang dilihat melalui perspektif auditor. Komite audit yang efektif dapat meningkatkan kualitas tata kelola perusahaan. Auditor percaya bahwa resiko inheren dapat lebih rendah apabila komite audit dalam perusahaan efektif menjalankan tugasnya, pada akhirnya akan mengurangi biaya audit yang dibebankan kepada perusahaan (Wahab et al, 2011). Pada sisi permintaan permintaan yang dijelaskan oleh Hey et al. (2006) biaya audit yang dibayar oleh perusahaan ditentukan oleh perusahaan sebagai pengguna. Efektivitas fungsi pengawasan yang dilakukan oleh Dewan Komisaris dan dibantu oleh Komite Audit. Perusahaan meminta kualitas layanan audit yang lebih tinggi dan meminta prosedur audit lebih menyeluruh. Hal ini dapat berimplikasi pada tingginya jumlah biaya audit yang dibebankan auditor.

$\mathrm{H}_{1}$ : Efektifitas komite audit berpengaruh terhadap biaya audit.

Struktur tata kelola perusahaan di Indonesia, dewan komisaris melakukan pengawasan dan memberikan nasehat pada dewan direksi untuk tercapainya tata kelola perusahaan yang baik. Dewan komisaris dalam menjalankan fungsinya sebagai pengawas membentuk komite-komite dibawahnya, seperti komite audit. Suatu perusahaan dapat dikatakan baik apabila sudah sesuai dengan standart Organisation for Economic Co-operation and Development (OECD) yang berlaku di Indonesia.

Dewan komisaris independen akan menuntut kualitas yang lebih tinggi dari proses audit yang dilakukanoleh auditor indpenden, hal tersebut akan mengakhibatkan biaya audit yang akan dikenakan lebih tinggi. Dewan komisaris independen akan mencoba yang terbaik untuk mempertahankan reputasi mereka dan untuk memenuhi fungsinya sebagai pengawas perusahaan. Pada akhirnya dewan komisaris bersedia membaya biaya audit lebih tinggi untuk mendapatkan audit yang berkualitas (Wilasti, 2017).

$\mathrm{H}_{2}$ : Dewan Komisaris Independen berpengaruh positif terhadap biaya audit.

\section{METODE PENELITIAN}

Populasi dalam penelitian ini adalah seluruh perusahaan yang terdaftar di Bursa Efek Indonesia (BEI) kecuali perusahaan keuangan tahun 2015-2018. Penelitian mulai dilakukan ditahun 2015 dikarenakan tepat pada tahun pemerintahan jokowi. Jenis data dalam penelitian ini merupakan data sekunder yang diambil 
dari informasi yang tersaji pada Annual Report. Sebanyak 584 perusahaan terpilih menjadi sampel penelitian berdasarkan teknik purposive sampling dengan kriteria pada Tabel 1.

\section{Tabel 1. Sampel Penelitian}

\begin{tabular}{|c|c|c|c|c|c|}
\hline No & Kriteria Sampel & 2015 & 2016 & 2017 & 2018 \\
\hline 1 & Perusahaan yang terdaftar di BEI & 510 & 525 & 510 & 540 \\
\hline 2 & Perusahaan Industri Keuangan & (80) & (82) & (87) & (87) \\
\hline 3 & $\begin{array}{l}\text { Laporan keuangan tidak dapat } \\
\text { diakses }\end{array}$ & (95) & (64) & $(46)$ & (97) \\
\hline \multirow[t]{3}{*}{4} & $\begin{array}{l}\text { Perusahaan yang } \\
\text { tidakmengungkapkan biaya audit }\end{array}$ & (232) & $(230)$ & (255) & (216) \\
\hline & Total & 103 & 149 & 192 & 140 \\
\hline & Total Observasi & & 584 & & \\
\hline
\end{tabular}

Sumber: Data Penelitian, 2019

Variabel dependen penelitian adalah biaya audit yang didefiniskan sebagai jumlah biaya yang harus dikeluarkan oleh setiap perusahaan untuk membiayai jasa auditor eksternal yang telah melakukan audit atas laporan keuangan perusahaan yang bersangkutan. Biaya audit diukur dengan logaritma natural biaya audit yang terdapat dalam laporan keuangan.

Variabel independen adalah efektivitas komite audit yang di definisikan sebagai komite yang memenuhi syarat untuk melindungi kepentingan dari pemegang saham untuk memastikan bahwa pelaporan keuangan andal, pengendalian internal, dan risiko manajemen, melalui upaya melaksanakan pengawasan dengan tekun. Efektivitas komite audit diukur dengan indeks komposit (EFFAC5) dikonfirmasi ketika kelima karakteristik. Lima karakteristik gabungan adalah sebagai berikut: independensi komite audit (IAC), keahlian komite audit (ACEXP), ketekunan komite audit (ACD), ukuran komite audit (SAC) dan ketua komite audit dengan keahlian akuntansi (ACCHX). Sistem skor digunakan dimana nilai dikotomis dari"1" atau "0" untuk setiap karakteristik komite audit yang efektif (Ali et al., 2018), setelah nilai dari skor efektivitas didapat dirasiokan dengan skor efektivitas komite audit dalam perusahaan dibagi nilai skor sempurna.

Variabel independen yang kedua adalah dewan komisaris independen yakni dewan komisaris yang tidak memiliki hubungan dengan direksi, anggota dewan komisaris lainnya dan pemegang saham. Dewan komisaris diukur menggunkan proporsi independen yaitu, jumlah dewan komisaris independen dibagi dengan jumlah di dewan komsaris masing-masing perusahaan (Chen \& Nowland, 2010), (García-Ramos \& García-Olalla, 2014) dan (Huang, 2010).

Rasio Dewan Komisaris Independen $=\frac{\text { jumlah komisaris independen }}{\text { jumlah dewan komisaris }}$

Variabel Kontrol penelitian adalah kantor akuntan publik, return on asset (ROA), dan ukuran perusahaan. Kantor akuntan publik diukur dengan variabel dummy. Kode 1 diberikan pada perusahaan yang menggunakan jasa akuntan publik big 4 dan kode 0 diberikan pada perusahaan yang menggunakan jasa akuntan publik non big 4 . ROA diukur menggunkan pendapatan operasional setelah pajak dibagi total asset. Ukuran perusahaan diukur menggunakan logaritma natural dari total asset. 
ROA $=\underline{\text { Pendapatan Operasional Setelah pajak }}$

Adapun teknik analisis yang digunakan meliputi analisis statistika deskriptif, uji asumsi klasik, dan uji hipotesis (Ghozali, 2011). Analisis statistika deskriptif berisi informasi mengenai karakteristik data penelitian berupa nilai minimum, nilai maksimum, nilai rata-rata dan standar deviasi. Pengujianhipotesis dilakukan menggunakan analisis regresi linear berganda. Berikut model persamaan regresi dalam penelitian ini sebagai berikut.

LAudFeeit $=a_{0}+\beta_{1}$ IndBOCit $+\beta_{2}$ EFFACit $+\beta \beta_{3}$ BIG4it $+\beta_{4}$ ROAit $+\beta_{5}$ SIZEit + cit.......

Keterangan:

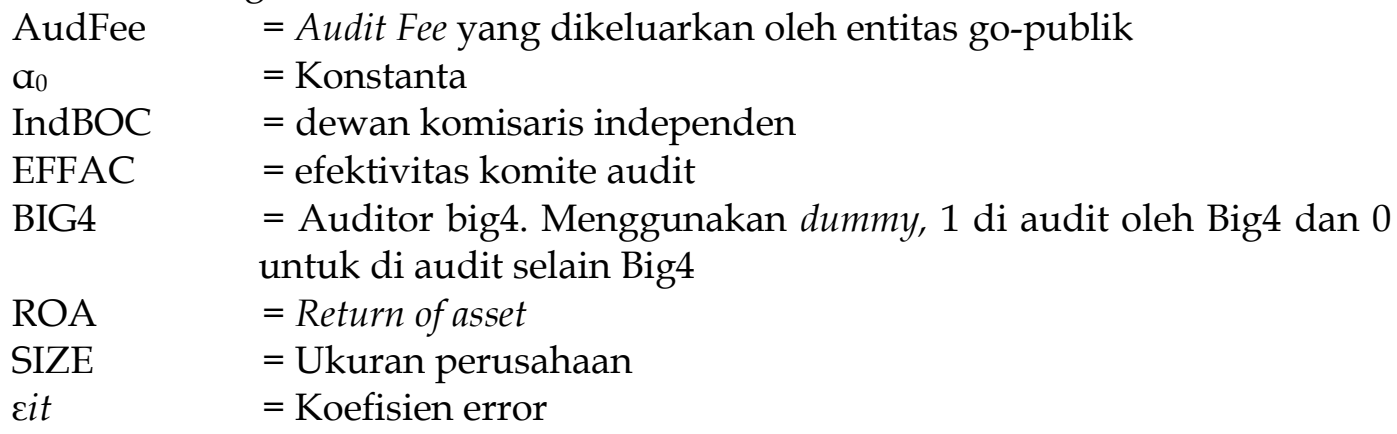

\section{HASIL DAN PEMBAHASAN}

Berdasarkan tabel statistik deskriptif, dapat diketahui bahwa variabel dependen dalam penelitian ini yaitu biaya audit memiliki nilai rata-rata sebesar 20,5303 yakni sebesar Rp 775 juta, ini berarti bahwa rata-rata perusahaan di Indonesi pada 2015 sampai 2018 membayar jumlah biaya audit sebesar Rp 775 juta kepada auditor. Rentang ini cukup tinggi pada variabel ini, dilihat dari perbedaan antara nilai maksimum dan minimum, menggambarkan bahwa sampel perusahaan dalam penelitian ini mewakili jumlah nominal biaya audit dari kecil ke besar.

Efektivitas komite audit yang diukur dengan lima karakteristik digunakan dalam penelitianAli et al. (2018) kemudian dilakukan pembagian skor efektivitas setiap perusahaan dibagi nilai sempurna. Nilai rata-rata yang diperoleh adalah 0,8045. Hasil menunjukan bahwa rata-rata sampel dalam perusahaan memiliki nikai efektivitas komite audit cukup baik. Nilai rata-rata pada penelitian Ali et al. (2018) sebesar 4 jika dirasiokan menjadi 0,8 diperoleh dari skor 4 pada lima karakteristik efektivitas komite audit. Skor maksimum 1 diperoleh apabila perusahaan memiliki skor 5 pada penilaian efektivitas komite audit.

Variebel independen kedua yakni dewan komisaris independen diukur ratio dewan komisaris independen dibagi jumlah total dewan komisaris (Chen \& Nowland, 2010), (García-Ramos \& García-Olalla, 2014) dan (Huang, 2010). Hasil rata-rata menunjukan 0,4052 nilai maksimum 1 diperoleh untuk perusahaan yang semua dewan komisaris yang dimiliki yakni komisaris independen. 
Tabel 2. Statistik deskriptif

\begin{tabular}{|c|c|c|c|c|c|}
\hline & $\mathrm{N}$ & Minimum & Maximum & Mean & Std. Deviation \\
\hline Fee & 584 & 18,29 & 24.11 & 20.5303 & 1.04974 \\
\hline Komite & 584 & .40 & 1.00 & .8045 & .14554 \\
\hline komisaris & 584 & 0.17 & 1.00 & .4052 & .11471 \\
\hline aset & 584 & 19.81 & 32.27 & 28.9478 & 1.60631 \\
\hline roa & 584 & -0.66 & 0,90 & 0.0429 & 0.10616 \\
\hline $\begin{array}{l}\text { Valid } \quad \mathrm{N} \\
\text { (listwise) } \\
\text { Variabel Dummy }\end{array}$ & 584 & & & & \\
\hline Variabel & \%Score1 & & $\%$ Score0 & total $\%$ & \\
\hline kap & (257) $44 \%$ & & (327) $56 \%$ & (584) $100 \%$ & \\
\hline
\end{tabular}

Sumber: Data Penelitian, 2019

Penelitian ini di Uji dengan uji regresi linier berganda. Sebelum di lakukan uji regresi linier berganda peneliti melakukan uji asumsi klasik yakni uji normalitas data, uji heterokedastisitas, dan uji multikolinearitas. Uji asumsi klasik dilakukan untuk mengetahui data penelitian yang sudah terdistribusi normal dan data bebas dari heterokedastisitas dan multikolinearitas. Model penelitian ini sudah layak dilakukan uji regresi linear berganda karena sudah lolos dari uji asumsi klasik.

Nilai adjusted $R 2$ pada Tabel 3 memiliki nilai sebesar 0.494 yang artinya variasi variabel efektivitas komite audit dan komisaris independen mampu menjelaskan variabel dependen yaitu biaya audit sebesar 49,4\% sementara 50.6\% sisanya dipengaruhi oleh faktor lain diluar model penelitian yang tidak dipilih sebagai variabel dependen. Selanjutnya uji F menunjukan nilai signifikansi sebesar 0.000 yang mengindikasikan bahwa pengujian secara simultan atau bersama-sama variabel independen berpengaruh signifikan terhadap variabel dependen.

Tabel 3. Uji Statistik

\begin{tabular}{|c|c|c|c|}
\hline Variabel & Coefficients & $t$-statistic & sig \\
\hline Constant & 11.688 & 0.627 & .000 \\
\hline komite & -.714 & -3.343 & .001 \\
\hline Komisaris & -.505 & 1.867 & .062 \\
\hline kap & .771 & 11.556 & .000 \\
\hline roa & .280 & .946 & .344 \\
\hline aset & .306 & 14.916 & .000 \\
\hline Uji F & & .000 & \\
\hline Adjusted $\mathrm{R}^{2}$ & & .494 & \\
\hline $\mathrm{N}$ & & 584 & \\
\hline
\end{tabular}

Sumber: Data Penelitian, 2019

Penelitian ini menggunakan sampel seluruh perusahaan yang terdaftar pada bursa efek Indonesia kecuali perusahaan keuangan, menggunakan sample sebnayak 584 perusahaan yang mengungkapkan biaya audit pada annual report. Sample sebanyak 584 diolah menggunakan SPSS versi 20 dan dilakukan regresi linier berganda untuk menguji variabel efektivitas komite audit terhadap biaya audit dengan variabel control yakni ROA, ukuran perusahaan dan kantor akuntan publik. 
Hasil penelitian yang dilakukan untuk hipotesis pertama menunjukan bahwa hipotesis kedua dalam penelitian ini diterima. Hipotesis kedua menyatakan bahwa efektivitas komite audit berpengaruh negatif terhadap biaya audit. Tingkat signifikansi sebesar $5 \%(0.001<0.05)$, sehingga $\mathrm{H}_{1}$ diterima. Penjelasan hasil dalam penelitian ini biaya audit dilihat dari perspektif auditor sebagai penyedia jasa audit yang harus dibayarkan Hey et al., (2006). Komite audit yang efektif meningkatkan tata kelola. Auditor percaya bahwa resiko yang dimiliki perusahaan bisa diminimalisir dengan komite audit yang efektif dalam menjalankan fungsinya, pada akhirnya akan menurunkan biaya audit yang harus dibayarkan pada perusahaan (Wahab et al, 2011).

Hasil penelitian mendukung argument pertama dalam sisi penawaran yang dilihat melalui perspektif auditor. Komite audit yang efektif dapat meningkatkan kualitas tata kelola perusahaan. Auditor percaya bahwa resiko inheren dapat lebih rendah apabila komite audit dalam perusahaan efektif menjalankan tugasnya, pada akhirnya kan mengurangi biaya audit yang dibebankan kepada perusahaan (Wahab et al, 2011). Hasil penelitian ini mendukung teori penentuan biaya audit yang menyatakan bahwa komite audit dapat menurunkan biaya audit dikarenakan biaya audit dapat diminimalisir dengan adnya komite audit yang efektif.

Penelitian ini menggunakan sampel seluruh perusahaan yang terdaftar pada bursa efek Indonesia kecuali perusahaan keuangan, menggunakan sample sebnayak 584 perusahaan yang mengungkapkan biaya audit pada annual report. Sample sebanyak 584 diolah menggunakan SPSS versi 20 dan dilakukan regresi linier berganda untuk menguji variabel dewan komisaris independen terhadap biaya audit dengan variabel control yakni ROA, ukuran perusahaan dan kantor akuntan publik.

Hasil penelitian yang dilakukan untuk hipotesis kedua menunjukan bahwa hipotesis kedua dalam penelitian ini diterima. Hipotesis kedua menyatakan bahwa dewan komisaris independen berpengaruh positif terhadap biaya audit. Tingkat signifikansi sebesar $10 \%(0.062<0.10)$, sehingga $\mathrm{H}_{1}$ diterima sesuai dengan penelitian (Wilasti, 2017). Penejlasan hasil dalam penelitian ini dewan komisaris menuntut kualitas yang tinggi dari proses audit yang dilakukan oleh akuntan publik, hal tersebut mengakhibatkan biaya audit dikenakan lebih tinggi.

Dewan komisaris merupakan pengawas dari perusahaan akan mempertahankan reputasi dengan menginginkan kualitas yang baik. Dewan komisaris memilih auditor yang mengaudit laporan dan meminta hsil audit yang maksimal, dan pada akhirnya perusahaan membayar biaya audit lebih tinggi untuk mendapatkan jasa audit yang berkualitas.

\section{SIMPULAN}

Penelitian ini bertujuan untuk menganalisis pengaruh efektivitas komite audit dan dewan komisaris independen terhadap biaya audit. Berdasarkan pengujian hipotesis pertama ditemukan bahwa komisaris independen berpengaruh positif terhadap biaya audit. Dewan komisaris independen akan menuntut kualitas yang lebih tinggi dari proses audit yang dilakukan oleh auditor indpenden, hal tersebut akan mengakhibatkan biaya audit yang akan dikenakan lebih tinggi. Dewan komisaris independen akan mencoba yang terbaik untuk 
mempertahankan reputasi mereka dan untuk memenuhi fungsinya sebagai pengawas perusahaan. Pada akhirnya dewan komisaris bersedia membaya biaya audit lebih tinggi untuk mendapatkan audit yang berkualitas. Hipotesis kedua ditemukan efektivitas komite audit berpengaruh negatif signifikan terhadap biaya audit. Hasil ini mendukung argument dari sisi penawaran Komite audit yang efektif dapat meningkatkan kualitas tata kelola perusahaan. Auditor percaya bahwa resiko inheren dapat lebih rendah apabila komite audit dalam perusahaan efektif menjalankan tugasnya, pada akhirnya kan mengurangi biaya audit yang dibebankan kepada perusahaan.

Penelitian ini memiliki keterbatasan, yang pertama masih sedikitnya perusahaan yang mengungkapkan biaya audit dalam laporan tahunannya, yang kedua di Indonesia masih belum ada sumber terpercaya yang menunjukan hubungan sesorang dengan politisi jadi kami hanya menggunakan media online sebagai informasi untuk mengetahui hubungan politik seseorang. Saran untuk penelitian selanjutnya untuk menambah variabel yang memiliki pengaruh terhadap biaya audit dan untuk peneli berikutnya untuk mencari sumber yang lebih akurat untuk hubunganseseorang dengan politik.

\section{REFERENSI}

Abbott, L. J., \& Parker, S. (2000). Auditor selection and audit committee characteristics. Auditing: A journal of practice $\mathcal{E}$ theory, 19(2), 47-66.

Ali, M. J., Singh, R. K. S., \& Al-Akra, M. (2018). The impact of audit committee effectiveness on audit fees and non-audit service fees: Evidence from Australia. Accounting Research Journal, 31(2), 174-191.

Arens, A. A., Elder, R. J., \& Beasly, m. S. (2014). Auditing and assurance services (15 edition ed.): pearson education.

Ariningrum, I., \& Diyanty, V. (2017). The Impact of Political Connections and the Effectiveness of Board of Commissioner and Audit Committees on Audit Fees. Australasian Accounting, Business and Finance Journal, 11(4), 53-70.

Arnold, V., Bedard, J. C., Phillips, J. R., \& Sutton, S. G. (2012). The impact of tagging qualitative financial information on investor decision making: implications for XBRL. International Journal of Accounting Information Systems, 13(1), 2-20.

Carcello, J. V., Hermanson, D. R., Neal, T. L., \& Riley Jr, R. A. (2002). Board characteristics and audit fees. Contemporary Accounting Research, 19(3), 365-384.

Chen, E. T., \& Nowland, J. (2010). Optimal board monitoring in family-owned companies: Evidence from Asia. Corporate Governance: An International Review, 18(1), 3-17.

Craswell, A. T., Francis, J. R., \& Taylor, S. L. (1995). Auditor brand name reputations and

Francis, J. R., \& Wilson, E. R. (1988). Auditor changes: A joint test of theories relating to agency costs and auditor differentiation. Accounting Review, 663-682.

García-Ramos, R., \& García-Olalla, M. (2014). Board independence and firm performance in Southern Europe: A contextual and contingency approach. Journal of Management E Organization, 20(3), 313-332. 
Ghosh, A. A., \& Tang, C. Y. (2015). Assessing financial reporting quality of family firms: The auditors' perspective. Journal of Accounting and Economics, 60(1), 95-116.

Ghozali, I. (2009). Ekonometrika, Teori dan Aplikasi dengan Program SPSS. Semarang: Badan Penerbit Universitas Diponegoro.

Ghozali, I. (2013). Analisis Multivariate dengan Program IBM SPSS 21: Semarang: Universitas Diponegoro.

Goodwin-Stewart, J., \& Kent, P. (2006). Relation between external audit fees, audit committee characteristics and internal audit. Accounting $\mathcal{E}$ Finance, 46(3), 387-404.

Huang, C.-J. (2010). Board, ownership and performance of banks with a dual board system: Evidence from Taiwan. Journal of Management $\mathcal{E}$ Organization, 16(2), 219-234.

Jensen, M. C., \& Meckling, W. H. (1976). Theory of the firm: Managerial behavior, agency costs and ownership structure. Journal of financial economics, 3(4), 305-360.

Johnson, S., \& Mitton, T. (2003). Cronyism and capital controls: evidence from Malaysia. Journal of Financial Economics, 67(2), 351-382.

Karamanou, I., \& Vafeas, N. (2005). The association between corporate boards, audit committees, and management earnings forecasts: An empirical analysis. Journal of Accounting Research, 43(3), 453-486.

Knechel, W. R., \& Willekens, M. (2006). The role of risk management and governance in determining audit demand. Journal of Business Finance $\mathcal{E}$ Accounting, 33(9-10), 1344-1367.

Kroszner, R. S., \& Stratmann, T. (1998). Interest-group competition and the organization of congress: theory and evidence from financial services' political action committees. American economic review, 1163-1187.

Li, H., Meng, L., Wang, Q., \& Zhou, L.-A. (2008). Political connections, financing and firm performance: Evidence from Chinese private firms. Journal of development economics, 87(2), 283-299.

Lin, J. W., Li, J. F., \& Yang, J. S. (2006). The effect of audit committee performance on earnings quality. Managerial Auditing Journal, 21(9), 921-933.

Musah, A. (2017). Determinants of audit fees in a developing economy: evidence from Ghana. International Journal of Academic Research in Business and Social Sciences, 7(11), 716-730.

Rittenberg, L. E., \& Nair, R. D. (1993). Improving the effectiveness of audit committees: Institute of Management Accountants.

Safari, M. (2017). Board and audit committee effectiveness in the post-ASX Corporate Governance Principles and Recommendations era. Managerial Finance, 43(10), 1137-1151.

Salehi, M., \& Shirazi, M. (2016). Audit committee impact on the quality of financial reporting and disclosure: Evidence from the Tehran Stock Exchange. Management Research Review, 39(12), 1639-1662.

Sulistyanto, S. (2008). Manajemen Laba (Teori \& Model Empiris): Grasindo.

Vafeas, N. (2005). Audit committees, boards, and the quality of reported earnings. Contemporary Accounting Research, 22(4), 1093-1122. 
Vafeas, N., \& Waegelein, J. F. (2007). The association between audit committees, compensation incentives, and corporate audit fees. Review of Quantitative Finance and Accounting, 28(3), 241-255.

Veronica, S., \& Bachtiar, Y. S. (2005). Corporate governance, information asymmetry, and earnings management. Jurnal Akuntansi dan Keuangan Indonesia, 2(1), 77-106.

Wahab, E. A. A., Zain, M. M., \& James, J. (2011). Political connections, corporate governance and audit fees in Malaysia. Managerial Auditing Journal, 26(5), 393-418.

Wahab, E. A. A., Zain, M. M., James, K., \& haron, H. (2009). Institutional investors, political connection and audit quality in Malaysia. Accounting Research Journal, 22(2), 167-195.

Walker, G. R., \& Reid, T. (2002). Upgrading corporate governance in East Asia: Part 1.

$\mathrm{Wu}, \mathrm{X} .$, \& Li, H. (2015). Board independence and the quality of board monitoring: Evidence from China. International Journal of Managerial Finance, 11(3), 308328.

$\mathrm{Yu}, \mathrm{F}$. , \& Yu, X. (2011). Corporate lobbying and fraud detection. Journal of Financial and Quantitative Analysis, 46(6), 1865-1891.

Zaman, M., Hudaib, M., \& Haniffa, R. (2011). Corporate governance quality, audit fees and non-audit services fees. Journal of Business Finance $\mathcal{E}$ Accounting, 38(1-2), 165-197. 